\title{
Microstructural Evolution of Cr-Rich ODS Steels as a Function of Heat Treatment at $475^{\circ} \mathrm{C}$
}

\author{
Zvi Foxman • Oded Sobol · Malki Pinkas • \\ Alex Landau • Peter Hähner • Vladimir Krsjak • \\ Louisa Meshi
}

Received: 3 August 2012/Revised: 21 August 2012/Published online: 22 September 2012

(C) Springer Science+Business Media, LLC and ASM International 2012

\begin{abstract}
In the current research, the effect of heat treatment on the morphology of the dispersoids and their phase composition were investigated in three Cr-rich ferritic oxide dispersion strengthened (ODS) steels: PM2000, MA956, and ODM751. The steels were aged at $475{ }^{\circ} \mathrm{C}$ for times ranging from 100 to $1,000 \mathrm{~h}$. The microstructure was characterized using transmission electron microscopy. Study of the as-recrystallized samples revealed nano-scale $\mathrm{Y}-\mathrm{Al}-\mathrm{O}$ complex-oxide particles dispersed in the ferritic matrix. These dispersoids, which differ in size (10-160 nm) and geometry (polygonal and spherical), were identified as $\mathrm{Y}_{4} \mathrm{Al}_{2} \mathrm{O}_{9}, \mathrm{YAlO}_{3}$, and $\mathrm{Y}_{3} \mathrm{Al}_{5} \mathrm{O}_{12}$. After heat treatment, a significant change in the morphology, size, and distribution of the dispersoids was observed. Changes in the phase composition of the oxide dispersoids were also observed: $\mathrm{YAlO}_{3}$ (with perovskite structure) was identified as the most dominant phase, indicating that it is probably the most stable phase in the Cr-rich ferritic ODS steels.
\end{abstract}

Z. Foxman · O. Sobol · L. Meshi $(\bowtie)$

Department of Materials Engineering, Ben-Gurion University of the Negev, P.O. Box 653, 84105 Beer Sheba, Israel

e-mail: louisa@bgu.ac.il

M. Pinkas - A. Landau

Nuclear Research Center-Negev, P.O. Box 9001, Beer Sheba, Israel

P. Hähner · V. Krsjak

Joint Research Centre, Institute for Energy, P.O. Box 2,

1755ZG Petten, The Netherlands
Keywords ODS steels $\cdot$ TEM $\cdot$ Microstructural characterization $\cdot$ Heat treatment

\section{Introduction}

Oxide dispersion strengthened (ODS) steels are known for their good mechanical strength, high creep resistance at temperatures up to $1,100{ }^{\circ} \mathrm{C}[1,2]$ and good radiation resistance. These properties make ODS alloys promising materials for high-temperature components, especially as structural materials for the next generation of nuclear reactors. Yet, there is some concern regarding the phenomenon known as " $475{ }^{\circ} \mathrm{C}$ Embrittlement" attributed to the decomposition of the ferritic matrix into $\alpha$ (Fe-rich) and $\alpha^{\prime}$ (Cr-rich) phases [3-6]. A detailed understanding regarding the effect of heat treatment at this intermediate temperature on the oxide dispersoids, which are responsible for superior strength and radiation resistance of these steels, is still needed. Moreover, there is disagreement among different researchers regarding the composition and structure of these oxides in the as-recrystallized state. Some authors state that the dispersoids have a $\mathrm{Y}-\mathrm{Al}-\mathrm{O}$ composition $[1,7,8]$, while others argue that they remain in their original form, as the $\mathrm{Y}_{2} \mathrm{O}_{3}$ particles that were added into the matrix during the mechanical alloying process [9, 10]. Possible structures of the oxide particles which can be found in ODS steels, according to the literature, are listed in Table 1.

The current research was undertaken with the purpose to perform in-depth characterization of the microstructure of three typical Cr-rich ferritic ODS steels, namely, MA956, PM2000, and ODM751. The as-recrystallized state was compared with features after aging at $475{ }^{\circ} \mathrm{C}$ for different periods of time. The evolution of the microstructure following these heat treatments is discussed. 


\section{Experimental}

Studied materials

Three commercial Cr-rich ferritic ODS steels (MA956, PM2000, and ODM751) were studied in the current work. The nominal chemical composition of the steels as measured by secondary ion mass spectroscopy (SIMS) is given in Table 2. As described in [11], manufacturing of ODS steels is accomplished by mechanical alloying processes which includes (i) mixing and milling of the matrix powders with yttria $\left(\mathrm{Y}_{2} \mathrm{O}_{3}\right)$ particles; (ii) consolidation by hot isostatic pressing (HIP) and extrusion; (iii) recrystallization at $\sim 0.9 T_{\text {melt }}$. In order to induce the intermediate temperature embrittlement, specimens were thermally aged at

Table 1 Possible structures of oxide particles in ODS steels, according to the literature $[9,18-22]$

\begin{tabular}{|c|c|c|c|}
\hline $\begin{array}{l}\text { Chemical } \\
\text { formula }\end{array}$ & Name & $\begin{array}{l}\text { Space } \\
\text { group }\end{array}$ & $\begin{array}{l}\text { Lattice } \\
\text { parameters } \\
\text { in } \AA\end{array}$ \\
\hline $\mathrm{Y}_{2} \mathrm{O}_{3}$ & Yttria & $I a \overline{\mathbf{3}}$ & $a=10.60$ \\
\hline $\mathrm{YAlO}_{3}$ & $\begin{array}{l}\text { Yttrium aluminum } \\
\text { perovskite (YAP) }\end{array}$ & Pnma & $\begin{aligned} a & =5.3286 \\
b & =7.3706 \\
c & =5.1796\end{aligned}$ \\
\hline $\mathrm{Y}_{3} \mathrm{Al}_{5} \mathrm{O}_{12}$ & $\begin{array}{l}\text { Yttrium aluminum } \\
\text { garnet (YAG) }\end{array}$ & $\operatorname{Ia3d}$ & $a=12.0089$ \\
\hline $\mathrm{Y}_{4} \mathrm{Al}_{2} \mathrm{O}_{9}$ & $\begin{array}{l}\text { Yttrium aluminum } \\
\text { monoclinic (YAM) }\end{array}$ & $P 2_{1} / a$ & $\begin{aligned} a & =11.1156 \\
b & =10.4689 \\
c & =7.3791 \\
\beta & =108.61^{\circ}\end{aligned}$ \\
\hline $\mathrm{YAlO}_{3}$ & $\begin{array}{l}\text { Yttrium aluminum } \\
\text { hexagonal (YAH) }\end{array}$ & $P 6_{3} / m m c$ & $\begin{array}{l}a=3.678 \\
c=10.483\end{array}$ \\
\hline $\mathrm{Y}_{3} \mathrm{Al}_{5} \mathrm{O}_{12}$ & $\begin{array}{l}\text { Yttrium Aluminite } \\
\text { Tetragonal (YAT) }\end{array}$ & I4 ${ }_{1} /$ amd & $\begin{array}{l}a=7.51 \\
c=4.24\end{array}$ \\
\hline $\mathrm{Al}_{2} \mathrm{O}_{3}-\alpha$ & Alumina alpha & $R \overline{3} c$ & $\begin{array}{l}a=4.75 \\
c=12.99\end{array}$ \\
\hline $\mathrm{Al}_{2} \mathrm{O}_{3}-\kappa$ & Alumina kappa & Pna $_{1}$ & $\begin{array}{l}a=4.83 \\
b=8.30 \\
c=8.93\end{array}$ \\
\hline $\mathrm{Al}_{2} \mathrm{O}_{3}-\gamma$ & Alumina gamma & $F d \overline{3} m$ & $a=7.952$ \\
\hline
\end{tabular}

$475^{\circ} \mathrm{C}$ for $100-1,000 \mathrm{~h}$ in a high-temperature furnace under Ar atmosphere of $5 \mathrm{mBar}$ overpressure.

\section{Transmission Electron Microscopy}

Samples for transmission electron microscopy were mechanically polished to a $100 \mu \mathrm{m}$ thickness on 600 grit $\mathrm{SiC}$ polishing paper. Disks, $3 \mathrm{~mm}$ in diameter, were then punched and electro-polished using $10 \% \mathrm{HClO}_{4}$ and $90 \%$ $\mathrm{CH}_{3} \mathrm{OH}$ as electrolyte, at $-16{ }^{\circ} \mathrm{C}$ with an applied voltage of $11.5 \mathrm{~V}$. TEM examination was performed at 120 or $200 \mathrm{kV}$; energy dispersive spectroscopy (EDS) was performed at $200 \mathrm{kV}$.

\section{Results}

\section{As-Recrystallized ODS Steels}

A general view of the microstructure of these alloys, as observed in bright field (BF) TEM, is shown in Fig. 1. The ferrite matrix is strain-free and exhibits very low defect density. The oxide particles are not uniformly distributed and some agglomeration is observed (although in the ODM751 it is less prominent). The discrete dispersoids appear in two main geometrical forms-polygonal (mainly cubic) and spherical, see insets in Fig. 1. The size of the dispersoids varies in the range of 10-90 $\mathrm{nm}$ for the MA956 and PM2000 steels and 15-160 nm for the ODM751.

The identification of the phase composition of the nano-metric oxide particles is not trivial, especially in the $\mathrm{Y}-\mathrm{Al}-\mathrm{O}$ system, which contains a series of oxide phases differing in either or both their stoichiometry and crystal structure, as listed in Table 1. Thus, phase characterization was performed through a combination of EDS and electron diffraction (ED) methods. It was found that in the as-recrystallized state, most oxide particles are composed of $\mathrm{Y}, \mathrm{Al}$, and $\mathrm{O}$ and they crystallize with YAP, YAG, and YAM structures (see Table 1, for clarification of abbreviations used). ED patterns collected from these particles were successfully indexed in terms of YAG and YAP unit

Table 2 Chemical composition of studied ODS steels

\begin{tabular}{|c|c|c|c|c|c|c|c|c|c|c|c|c|c|c|c|c|}
\hline \multirow[t]{2}{*}{ Steel } & \multicolumn{16}{|l|}{ Element } \\
\hline & $\mathrm{C}$ & $\mathrm{Si}$ & $\mathrm{Mn}$ & $\mathrm{P}$ & $\mathrm{S}$ & $\mathrm{Al}$ & $\mathrm{Nb}$ & $\mathrm{Ti}$ & Sn & Mo & $\mathrm{Ni}$ & Co & $\mathrm{Cr}$ & $\mathrm{Y}$ & B & $\mathrm{Fe}$ \\
\hline MA956 & 0.063 & 0.05 & 0.08 & 0.016 & 0.009 & 4.52 & 0.01 & 0.32 & 0.007 & 0.02 & 0.05 & 0.01 & 18.7 & 0.41 & $<0.005$ & Balance \\
\hline PM2000 & 0.069 & 0.05 & 0.02 & 0.011 & 0.008 & 5.87 & 0.01 & 0.47 & 0.008 & 0.01 & 0.03 & 0.02 & 19.3 & 0.43 & $<0.005$ & Balance \\
\hline ODM751 & $<0.01$ & 0.05 & 0.02 & 0.011 & 0.008 & 4.5 & 0.01 & 0.6 & 0.008 & 1.5 & 0.01 & 0.01 & 16.5 & 0.5 & $<0.005$ & Balance \\
\hline
\end{tabular}

The composition is given in wt.\% as investigated by SIMS 

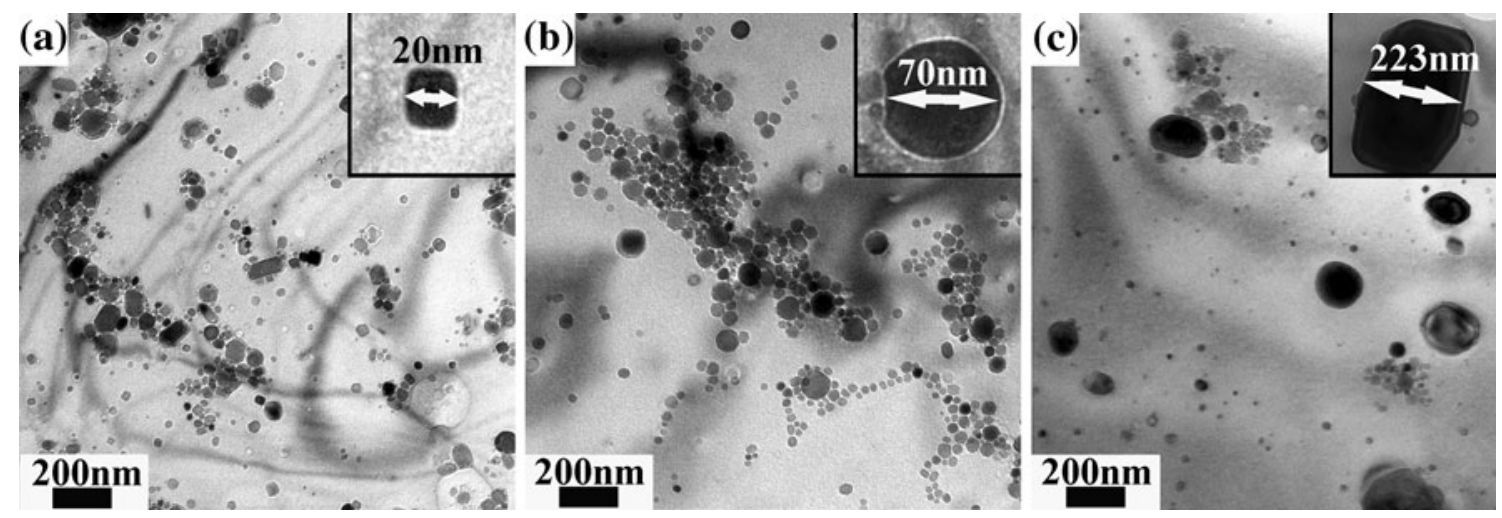

Fig. 1 General view of the different alloys in the as-recrystallized state a MA956, b PM2000, and c ODM751. Insets show enlarged images of individual oxide particles

Fig. 2 BF TEM images. a Individual YAM particles observed in the as-recrystallized MA956 steel. Selected area electron diffraction (SAED) pattern taken at [001] orientation is shown in the inset. b Individual YAP particles observed in the as-recrystallized ODM751 steel. SAED pattern taken at [1111] orientation is shown in the inset. c SAED taken from the as-recrystallized MA956 steel. Rings are indexed in terms of YAP unit cell. $(110)_{\mathrm{Fe}}$ reflections from the $\mathrm{Fe}$ matrix are marked by arrowheads
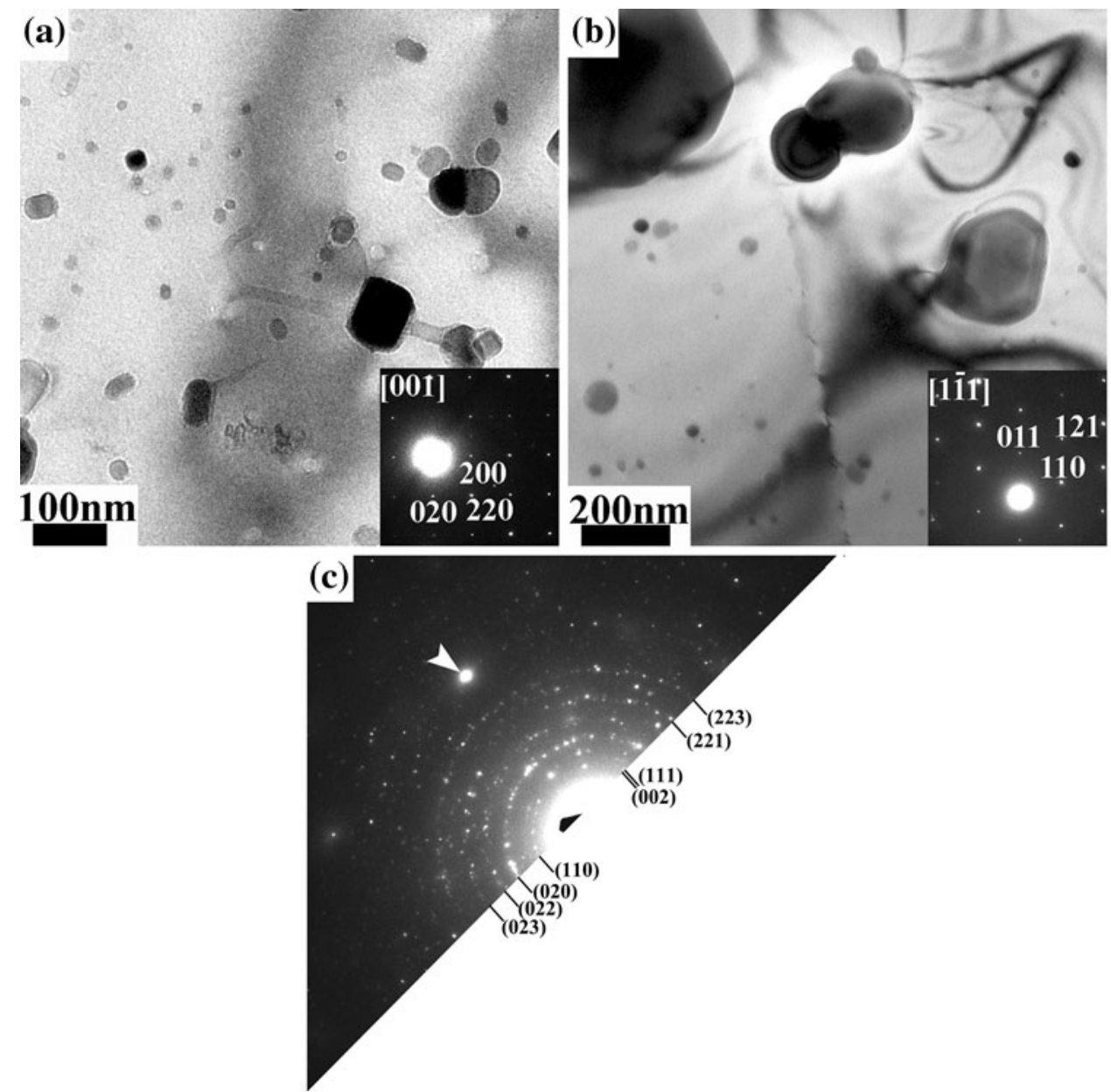

cells. Examples of the different oxide phases observed in the alloys in their as-recrystallized state are given in Fig. 2 The $\mathrm{Y}-\mathrm{Al}-\mathrm{O}$ particles appear without any orientation relationship with the matrix. In the MA956 steel, the $\mathrm{Y}-\mathrm{Al}-\mathrm{O}$ agglomerates produced an ED ring pattern which is an indication that the nano-metric dispersoids are randomly orientated in the matrix (see Fig. 3c).

It should be noted that $\mathrm{Al}_{2} \mathrm{O}_{3}$ and $\mathrm{Ti}(\mathrm{C}, \mathrm{N})$ inclusions were observed in an insignificant amount in all alloys investigated, while $\mathrm{Y}_{2} \mathrm{O}_{3}$ particles were not found at all. 

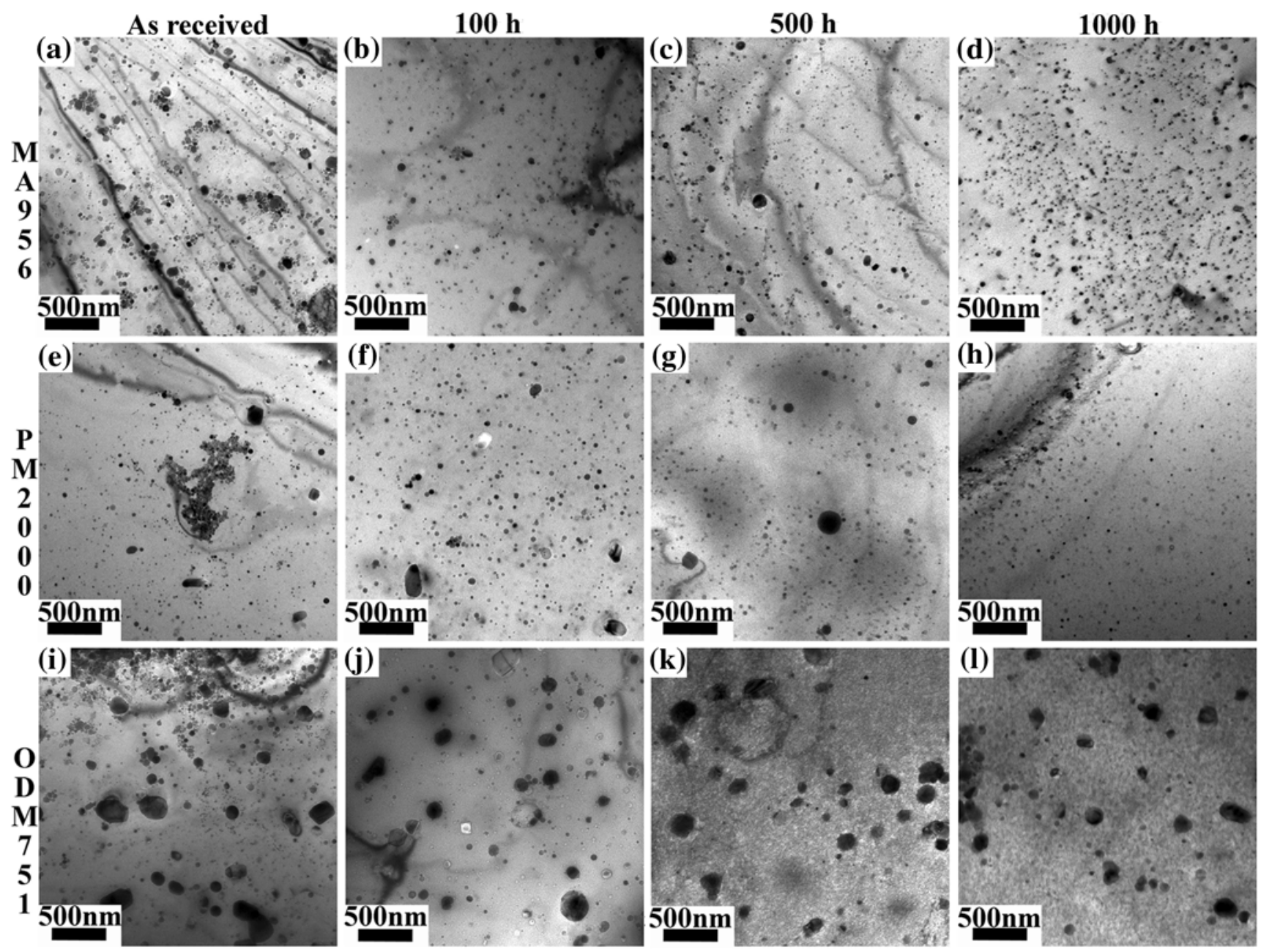

Fig. 3 General view of studied alloys after the heat treatment at $475{ }^{\circ} \mathrm{C}$ for different aging times. a, b, c, and d MA956 steel; e, f, g, and h PM2000 steel; i, j, k, and I ODM751 steel after HT for 0, 100, 500, and 1,000 h, respectively

\section{Effect of Heat Treatments}

Exposure at $475{ }^{\circ} \mathrm{C}$ led to morphological and structural modifications of the dispersoids in all steels investigated, but to a different extent depending on the alloy. The microstructural evolution as a function of heat treatment time can be clearly seen in Fig. 3. PM2000 and MA956 steels demonstrate a decreased extent of agglomeration after 1,000 h. Moreover, the TEM images imply that in the heat-treated PM2000 and MA956 samples, size and shape of the $\mathrm{Y}-\mathrm{Al}-\mathrm{O}$ dispersoids changes with exposure time $\left(\mathrm{Al}_{2} \mathrm{O}_{3}\right.$ particles do not change as a function of heat treatment time).

The $\mathrm{Y}-\mathrm{Al}-\mathrm{O}$ dispersoids found in these steels became smaller and a spherical shape became dominant. Furthermore, contrary to the random orientation of the dispersoids in the as-recrystallized condition, a distinct matrix/dispersoid orientation relationship was observed after $1,000 \mathrm{~h}$ of heat treatment. A typical superimposed matrix/dispersoid
ED pattern, shown in Fig. 4, illustrates the orientation relationship between the dispersoids and the matrix. The distinct orientation relationship coupled with the nanometric size of $\mathrm{Y}-\mathrm{Al}-\mathrm{O}$ particles and the close inter-planar spacings of the possible $\mathrm{Y}-\mathrm{Al}-\mathrm{O}$ structures, made the identification of their crystallographic structure using ED techniques very difficult and sometimes even impossible. Applying a fast Fourier transform (FFT) to high-resolution TEM (HRTEM), lattice images obtained from the dispersoids (see example in Fig. 5), revealed that the prevailing structure of the dispersoids in MA956 and PM2000 after $1,000 \mathrm{~h}$ at $475{ }^{\circ} \mathrm{C}$ is YAP. The orientation relationship between the YAP particles and the matrix was determined from ED patterns as

$$
[121]_{\mathrm{YAP}}\left\|[111]_{\mathrm{Fe}},(2 \overline{1} 0)_{\mathrm{YAP}}\right\|(\overline{1} 10)_{\mathrm{Fe}} \text {. }
$$

Contrary to the major microstructural changes observed in MA956 and PM20000 because of the heat treatment, no significant changes were observed in ODM751. Because the 


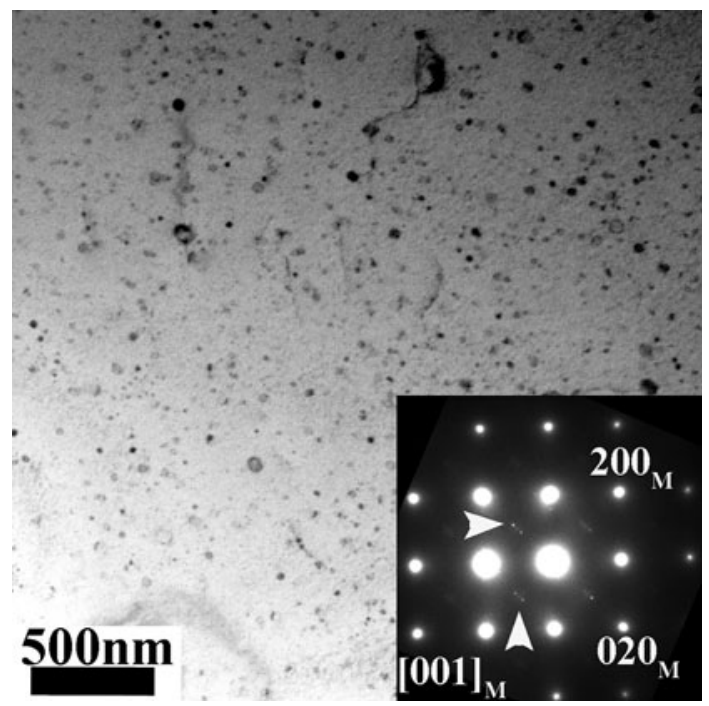

Fig. 4 Typical BF TEM image of PM2000 steel after HT for 1,000 h. ED pattern taken from the dispersoids is shown in the inset. ED is indexed in terms of ferrite phase, $\mathrm{M}$, ferrite matrix. Unindexed spots, marked by arrowheads, correspond to $\mathrm{Y}-\mathrm{Al}-\mathrm{O}$ dispersoid. Some spots appeared due to multiple scattering

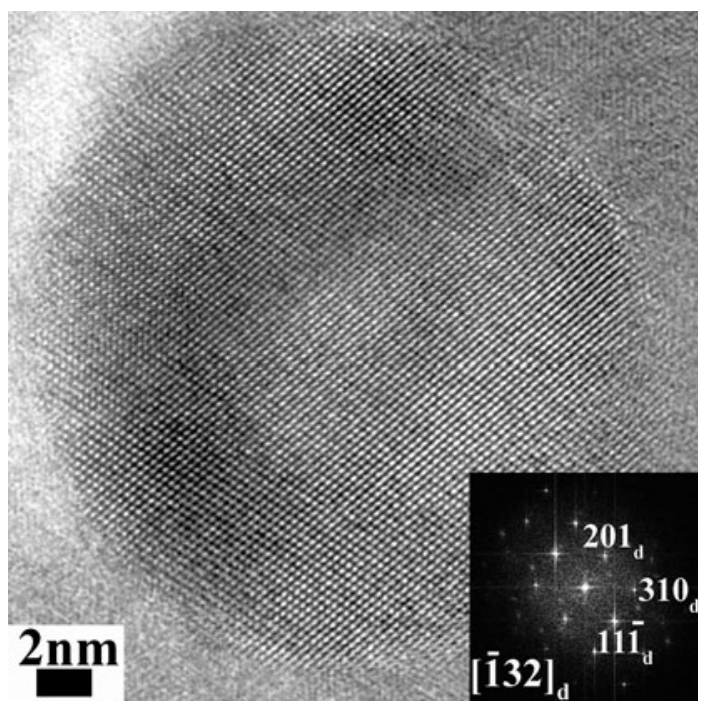

Fig. 5 HRTEM image of one dispersoid particle, taken from PM2000 alloy aged at $475{ }^{\circ} \mathrm{C}$ for $1,000 \mathrm{~h}$. FFT (taken from this image), indexed in terms of perovskite YAP structure, is shown in the inset, $\mathrm{d}$, dispersoid's diffraction nodes

average dispersoid size found in this ODM steel was larger, the characterization of their structure was performed by ED. Typical particles found in ODM751 after the heat treatment and their corresponding ED patterns are shown in Fig. 6.

With regard to the ferrite matrix, an EDS line scan did not show variations in the Cr composition. Thus, $\alpha^{\prime}$ formation was not confirmed using analytical methods. On the other hand, changes in the $\mathrm{Al}$ content within the matrix

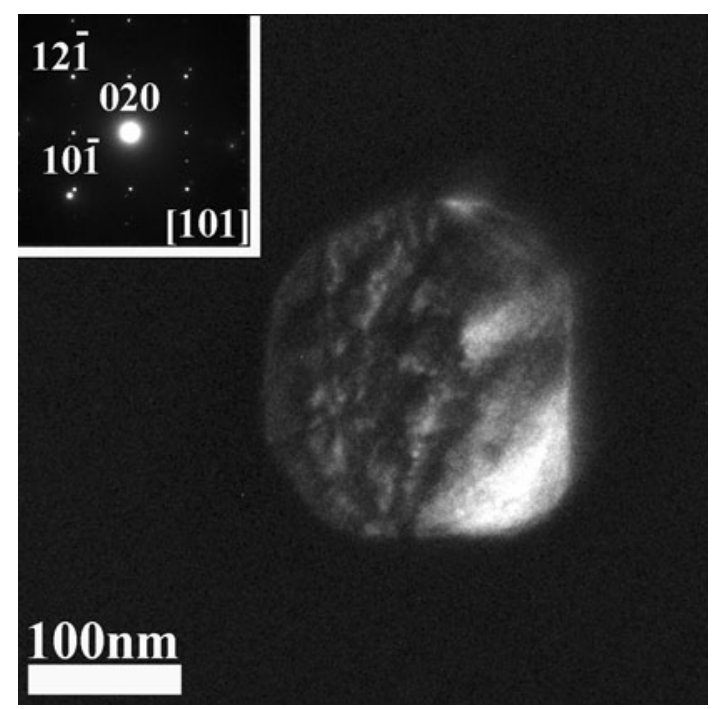

Fig. 6 Dark field (DF) TEM image of YAP particle found at the ODM751 steel after HT for $500 \mathrm{~h}$. ED pattern, indexed in terms of perovskite structure, is shown in the inset. DF image was taken at $g=020$

were observed after the heat treatments. Concentrations of 2-4 and 5-7 at.\% of $\mathrm{Al}$ (depending on the type of ODS steel studied) were measured in the ferritic matrix before and after heat treatment, respectively (see Fig. 7a-c). Although the difference may appear to be negligible, all three ODS steels studied in this research exhibited noticeable 2-3 at.\% changes in $\mathrm{Al}$ content in the ferritic matrix following the prolonged heat treatment. For example, Fig. 7 shows EDS line scans taken in scanning TEM (STEM) mode from PM2000. Scan length is about $500 \mathrm{~nm}$ in the as-received sample and about $1 \mu \mathrm{m}$ in the sample after the heat treatment for $1,000 \mathrm{~h}$. These line scans were performed using a $0.8 \mathrm{~nm}$ diameter probe, and reveal the difference in $\mathrm{Al}$ content after heat treatment.

\section{Discussion}

Microstructural characterization of MA956, PM2000, and ODM751 steels has revealed similarity between MA956 and PM2000 alloys. The fact that no $\mathrm{Y}_{2} \mathrm{O}_{3}$ particles were observed in any of the investigated steels is likely the result of the reaction of $\mathrm{Al}$ with $\mathrm{Y}_{2} \mathrm{O}_{3}$ during the high-temperature pressing leading to the formation of $\mathrm{Y}-\mathrm{Al}-\mathrm{O}$ particles [7, 12]. The exact composition and crystallographic structure of these $\mathrm{Y}-\mathrm{Al}-\mathrm{O}$ compounds depend on the local composition of the matrix. Thus, it is reasonable to obtain non-equilibrium $\mathrm{Y}-\mathrm{Al}-\mathrm{O}$ compounds in the as-recrystallized state even when the consolidation process is conducted at high temperature $\left(T \sim 1,150{ }^{\circ} \mathrm{C}\right)$ because its duration may not be sufficient for achieving an equilibrium state. 

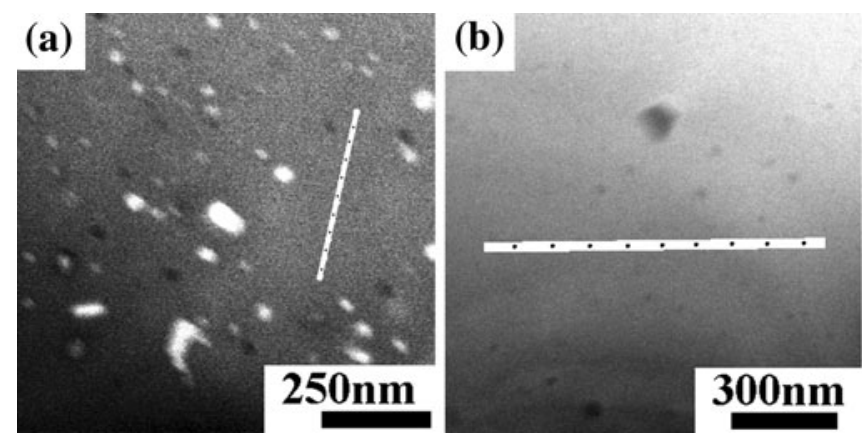

Fig. 7 DF STEM images of PM2000 matrix grains with scan position shown by white line, a before and $\mathbf{b}$ after aging for $1,000 \mathrm{~h}$. c Corresponding EDS line scan results. For simplicity, only Al

These results imply that additional heat treatment (at $475^{\circ} \mathrm{C}$ ) for long periods of time induces significant structural changes in these ODS alloys. In the as-recrystallized state, large amounts of YAG and YAM were observed; after prolonged heat treatment, the YAP perovskite structure of $\mathrm{Y}-\mathrm{Al}-\mathrm{O}$ compounds dominates. In the literature, there are different reports regarding the stability of the phases in the $\mathrm{Y}-\mathrm{Al}-\mathrm{O}$ system and it appears that phase stability depends on the composition of the surrounding matrix. In studies of the stability of $\mathrm{Y}-\mathrm{Al}-\mathrm{O}$ phases that focused on the $\mathrm{Y}_{2} \mathrm{O}_{3}-\mathrm{Al}_{2} \mathrm{O}_{3}$ system, it was concluded that YAG is the most stable phase $[13,14]$. In a study focusing on a nickel-based austenitic steel (PM6000), Schaffer et al. [15] concluded that the YAH is the most stable phase. Our results suggest that in the Cr-rich ferritic matrix of the ODS steels studied, YAP is the most stable phase.

The disappearance of the agglomerates and the refinement of dispersoid size are also motivated by the desire of the system to attain equilibrium. It is known that at lower temperatures (such as $475^{\circ} \mathrm{C}$ ), the YAM phase becomes unstable and decomposes to a mixture of YAP and yttria [14]. Thus, the fact that YAM has disappeared during heat treatment was not a surprise. However, these results suggest that YAG-YAP phase transformation has also occurred in our samples. This can be explained by a congruent dissolution-precipitation mechanism [16, 17]. During the heat treatment, YAG phase dissolves into the ferritic matrix and YAP precipitates. The orientation relationship between the YAP spherical particles (found in the samples after the $1,000 \mathrm{~h}$ heat treatment) and the ferritic matrix is an indication that these particles nucleate and grow from the ferritic matrix. Al-rich matrix around newly formed YAP particles in the PM2000 and MA956 samples after the $1,000 \mathrm{~h}$ heat treatment (see Fig. 7c) provides an additional proof to the proposed dissolution-precipitation mechanism. The YAG-YAP phase transformation requires a decrease in $\mathrm{Al}$ content, as illustrated from the stoichiometry of these

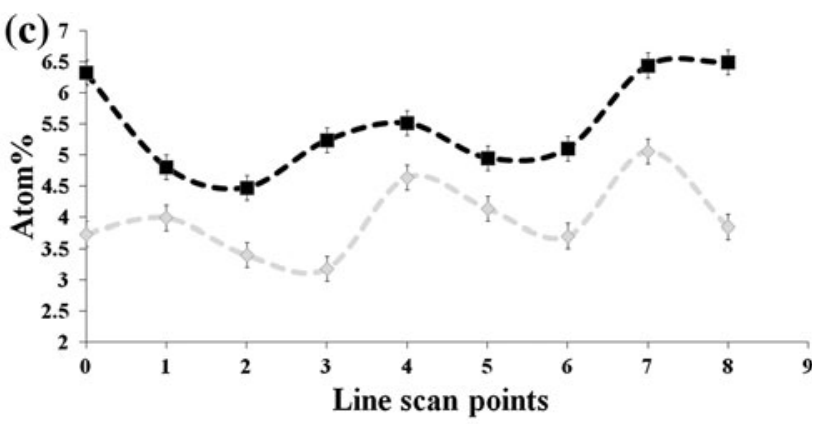

quantities are shown. Gray and black lines show $\mathrm{Al}$ amount in the $\mathrm{Fe}$ matrix before and after the heat treatment, respectively

phases presented in Table 1. It is reasonable to suggest that during the dissolution part of this transformation, $\mathrm{Al}$ has diffused out of the original YAG phase, the stoichiometry of the particle has changed, and YAP precipitates. Such a mechanism explains the relative increase of $\mathrm{Al}$ in the matrix around small YAP particles after the heat treatment. Yet, this mechanism is not entirely understood and should be further investigated.

In contrast to the other steel studied, the dispersoids in the ODM751 did not undergo significant structural change. It can be proposed that the reason for this is a relatively low $\mathrm{Cr}$ and high Mo and Ti content compared to the PM2000 and MA956 steels (see Table 2). This difference in composition changes the diffusion coefficient and stabilizes the $\mathrm{Y}-\mathrm{Al}-\mathrm{O}$ particles (thus they are initially larger than in other alloys). Therefore, ODM751 probably attains equilibrium during the recrystallization process and this is the reason why no significant microstructural changes occur during the prolonged heat treatment.

Because the " $475{ }^{\circ} \mathrm{C}$ Embrittlement" was observed in all the three alloys, reported here, the effect of microstructural evolution of $\mathrm{Y}-\mathrm{Al}-\mathrm{O}$ precipitates does not explain this phenomenon. On the other hand, although $\alpha^{\prime}$ formation was not confirmed in this article, its formation is assumed, and may be the reason for the embrittlement.

\section{Conclusion}

The effect of exposure to $475{ }^{\circ} \mathrm{C}$ of the three $\mathrm{Cr}$-rich ferritic ODS steels, MA956, PM2000, and ODM751, on dispersoid morphology and composition was investigated using transmission electron microscopy.

Aging at $475{ }^{\circ} \mathrm{C}$ induced morphological modifications mostly in the MA956 and PM2000 steels. The large agglomerates prevailing in the as-recrystallized state disappeared, while fine, well-oriented, and evenly distributed particles were formed after the heat treatment. In the 
as-recrystallized state, the dispersoids possessed YAP, YAG, and YAM structures. After $1,000 \mathrm{~h}$ at $475{ }^{\circ} \mathrm{C}$, only YAP was identified in the PM2000 and MA956 steels. Formation of YAP phase during the heat treatment was explained through a congruent dissolution precipitation mechanism.

\section{References}

1. A. Czyrska Filemonowicz, B. Dubiel, Mechanically alloyed, ferritic oxide dispersion strengthened alloys: structure and properties. J. Mater. Process. Technol. 64, 53-64 (1997)

2. M.S. El-Genk, J. Tournier, A review of refractory metal alloys and mechanically alloyed-oxide dispersion strengthened steels for space nuclear power systems. J. Nucl. Mater. 340, 93-112 (2005)

3. C. Capdevila, M.K. Miller, K.F. Russell, J. Chao, J.L. GonzalezCarrasco, Phase separation in PM 2000 (TM) Fe-base ODS alloy: experimental study at the atomic level. Mater. Sci. Eng. A 490(2008), 277-288 (2000)

4. C. Capdevila, M.K. Miller, I. Toda, J. Chao, Influence of the alpha-alpha' ${ }^{\prime}$ hase separation on the tensile properties of Fe-base ODS PM 2000 alloy. Mater. Sci. Eng. A 527, 7931-7938 (2010)

5. S. Kobayashi, T. Takasugi, Mapping of 475 degrees C embrittlement in ferritic Fe-Cr-Al alloys. Scripta Mater. 63, 1104-1107 (2010)

6. J. Chao, J. Gonzalez-Carrasco, The influence of processing on the 475 degrees C hardening of MA 956 alloy RID A-7971-2008. Scripta Mater. 47, 423-428 (2002)

7. M. Klimiankou, R. Lindau, A. Moslang, J. Schroder, TEM study of PM 2000 steel. Powder Metall. 48, 277-287 (2005)

8. M. Hupalo, M. Terada, A. Kliauga, A. Padilha, Microstructural characterization of INCOLOY alloy MA 956. Materialwiss. Werkstofftech. 34, 505-508 (2003)

9. H. Bhadeshia, Recrystallisation of practical mechanically alloyed iron-base and nickel-base superalloys. Mater. Sci. Eng. A. 223, 64-77 (1997)

10. M. Klimiankou, R. Lindau, A. Moslang, HRTEM Study of yttrium oxide particles in ODS steels for fusion reactor application. J. Cryst. Growth 249, 381-387 (2003)
11. S. Ukai, T. Nishida, H. Okada, T. Okuda, M. Fujiwara, K. Asabe, Development of oxide dispersion strengthened ferritic steels for FBR core application. 1. Improvement of mechanical properties by recrystallization processing. J. Nucl. Sci. Technol. 34, 256-263 (1997)

12. A. Czyrska-Filemonowicz, K. Szot, A. Wasilkowska, A. Gil, W. Quadakkers, Microscopy (AFM, TEM, SEM) studies of oxide scale formation on FeCrAl based ODS alloys. Solid State Ionics 117, 13-20 (1999)

13. J.S. Abell, I.R. Harris, B. Cockayne, B. Lent, An investigation of phase stability in the $\mathrm{Y}_{2} \mathrm{O}_{3}-\mathrm{AI}_{2} \mathrm{O}_{3}$ system. J. Mater. Sci. 9, 527-537 (1974)

14. S. Barzilai, M. Aizenshtein, N. Froumin, N. Frage, Mechanism of interface interactions between thermodynamically stable oxides and Al containing melts. Adv. Appl. Ceram. 110, 15-19 (2011)

15. G. Schaffer, M. Loretto, R. Smallman, J. Brooks, The stability of the oxide dispersion in inconel alloy MA6000. Acta Metall. 37, 2551-2558 (1989)

16. S. Hayun, A. Weizmann, M.P. Dariel, N. Frage, Microstructural evolution during the infiltration of boron carbide with molten silicon. J. Eur. Ceram. Soc. 30, 1007-1014 (2010)

17. S. Hayun, N. Frage, M.P. Dariel, The morphology of ceramic phases in $\mathrm{B}(\mathrm{x}) \mathrm{C}-\mathrm{SiC}-\mathrm{Si}$ infiltrated composites. J. Solid State Chem. 179, 2875-2879 (2006)

18. W.Y. Ching, Y.N. Xu, Nonscalability and nontransferability in the electronic properties of the Y-Al-O system. Phys. Rev. B 59, 12815-12821 (1999)

19. H.S. Yoder, M.L. Keith, Complete substitution of $\mathrm{Al}$ for $\mathrm{Si}$ in the system $3 \mathrm{MnO} \cdot 3 \mathrm{SiO}_{2}-3 \mathrm{Y}_{2} \mathrm{O} \cdot 5 \mathrm{Al}_{2} \mathrm{O}_{3}$. Am. Mineral. 36, 519-533 (1951)

20. G. Paglia, C.E. Buckley, A.L. Rohl, B.A. Hunter, R.D. Hart, J.V. Hanna, L.T. Byrne, Tetragonal structure model for boehmitederived gamma-alumina. Phys. Rev. B 68, 144110 (2003)

21. V. Langer, L. Smrcok, M. Halvarsson, Y. Yourdshahyan, C. Ruberto, S. Ruppi, Structure determination of kappa- $\mathrm{Al}_{2} \mathrm{O}_{3}$, Epdic 7: European Powder Diffraction, Pts 1 and 2, 378-3, pp. 600-605 (2001)

22. N. Ishizawa, T. Miyata, I. Minato, F. Marumo, S. Iwai, Structural investigation of alpha- $\mathrm{Al}_{2} \mathrm{O}_{3}$ at $2170-\mathrm{K}$. Acta Crystallographica Section B-Structural Science. 36, 228-230 (1980) 